\title{
ACUTE PHYSICAL EXERCISE AND HYPERTENSION IN THE ELDERLY: A SYSTEMATIC REVIEW
}

EXERCÍCIO FÍSICO AGUDO E HIPERTENSÃO ARTERIAL EM IDOSOS: REVISÃO SISTEMÁTICA

EJERCICIO FISICO AGUDO E HIPERTENSIÓN ARTERIAL EN ANCIANOS: REVISIÓN SISTEMÁTICA

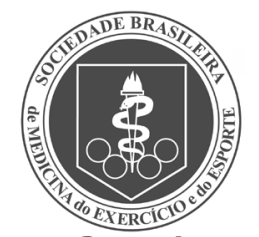

Systematic ReView Article

Artigo de ReVISÃo SISTEMÁtICA Artículo de ReVIsIón SISTEMÁtICA
Thaís Amanda Reia' ${ }^{\text {(DD }}$

Physical Education Professional

Roberta Fernanda da Silva' (ID

Physical Education Professional

André Mourão Jacomini ${ }^{1}$ (DD

Physical Education Professional

Ana Maria Guilmo Moreno' (ID

Physical Education Professional

Anderson Bernardino da Silva' (ID

Physical Education Professional

Henrique Luiz Monteiro ${ }^{1,2}$ (ID

Physical Education Professional

Anderson Saranz Zago 1,2 (DD

Physical Education Professional

1.Universidade Estadual Paulista (UNESP), Graduate Studies Program in Motricity Sciences, Bauru, São

Paulo, SP, Brazil.

2. Universidade Estadual Paulista (UNESP), Bauru, São Paulo, SP, Brazil.

\section{Correspondence:}

Anderson Saranz Zago.

Universidade Estadual Paulista (UNESP), Faculdade de Ciências (School of Sciences), Department of Physical Education, Bauru, São Paulo, SP, Brazil. Av. Eng. Luiz Edmundo Carrijo Coube, 14-01, Vargem Limpa, Bauru, São Paulo, SP, Brazil. 17033-360.

anderson.zago@unesp.br

\begin{abstract}
As the population ages, health conditions, including hypertension $(\mathrm{HT})$, which is one of the most prevalent diseases in the elderly population, increase. Regular physical exercise has been recommended for hypertensive individuals; however, due to the variety of factors involved in exercise, different acute responses can be achieved. Accordingly, the purpose of this study was to perform a systematic review of the acute effect of physical exercise on blood pressure (BP) in elderly hypertensive patients and of its applicability to the treatment of HT. The search was performed in electronic databases available at Pubmed/Medline, Scopus and Bireme from 2008 to 2018, using the terms "acute physical exercise and hypertension and elderly". A total of 592 articles were found, and after applying the inclusion criteria, 9 articles were selected to form the analysis. All studies evaluated the acute effect of the exercise session and the acute effect of the session after a training period in male and female hypertensive individuals aged 60 years or over. The results indicate that in spite of the heterogeneity of training methods, all intervention protocols used in these studies were effective in promoting BP reduction post exercise when compared to the control group. However, there is still a gap in the reviewed literature regarding the maintenance time of post exercise hypotension (PEH) in the elderly. This information could suggest how long individuals undergoing physical exercise would be "protected" from high blood pressure values and their health risks, and help plan physical exercise sessions at the precise time the hypotensive effect ceases to be present. Level of evidence Il; Therapeutic studies-Investigation of treatment results.
\end{abstract}

Keywords: Aging; Arterial hypertension; Physical exercise; Post-exercise hypotension.

\section{RESUMO}

À medida que a população envelhece, aumentam os agravos de saúde, entre eles, a hipertensão arterial (HA) destaca-se como uma das doenças de maior prevalência na população idosa. O exercício físico regular tem sido recomendado para indivíduos hipertensos, entretanto devido à variedade com que o exercício pode ser realizado, diferentes respostas agudas podem ser obtidas. Sendo assim, o objetivo do presente estudo consistiu em realizar uma revisão sistemática sobre o efeito agudo do exercício físico na pressão arterial (PA) em idosos hipertensos e sua aplicabilidade para o tratamento da HA. A busca foi realizada a partir de bancos de dados eletrônicos disponíveis no Pubmed/Medline, Scopus e Bireme de 2008 a 2018, utilizando os termos "acute physical exercise and hypertension and elderly". Foram encontrados 592 artigos e, após aplicar os critérios de inclusão, foram selecionados nove artigos que fizeram parte da análise, os quais avaliaram o efeito agudo da sessão de exercício e o efeito agudo da sessão após um período de treinamento em indivíduos hipertensos, com idade a partir de 60 anos, de ambos os sexos. Os resultados apontam que apesar da heterogeneidade nos métodos de treinamento, todos os protocolos de intervenção utilizados nesses estudos foram eficazes na promoção da redução da PA pós-exercício quando comparados ao grupo controle. No entanto, ainda existe uma lacuna na literatura revisada em relação ao tempo de manutenção da hipotensão pós-exercício (HPE) em idosos. Essa informação poderia sugerir por quanto tempo os praticantes estariam "protegidos" dos elevados valores pressóricos e seus riscos para a saúde e auxiliar no planejamento das sessões de exercício físico, justamente quando o efeito hipotensor estivesse deixando de se manifestar. Nível de evidência ll; Estudos terapêuticos-Investigação dos resultados do tratamento.

Descritores: Envelhecimento; Hipertensão arterial; Exercício físico; Hipotensão pós-exercício.

\section{RESUMEN}

A medida que la población envejece, aumentan los agravios de salud, entre ellos, la hipertensión arterial (HA) se destaca como una de las enfermedades de mayor prevalencia en la población anciana. El ejercicio físico regular ha sido recomendado para individuos hipertensos, sin embargo, debido a la variedad con que el ejercicio puede ser realizado, diferentes respuestas agudas pueden ser obtenidas. Siendo así, el objetivo del presente estudio consistió en realizar una revisión sistemática sobre el efecto agudo del ejercicio físico en la presión arterial (PA) en ancianos hipertensos y su aplicabilidad para el tratamiento de la HA. La búsqueda fue realizada a partir de bancos de datos electrónicos disponibles en el Pubmed/Medline, Scopus y Bireme de 2008 a 2018, utilizando los términos "acute physical exercise and hypertension and elderly."Se encontraron 592 artículos y, después de aplicar los criterios de inclusión, se seleccionaron nueve artículos que formaron parte del análisis, los cuales evaluaron el efecto agudo de la sesión de ejercicio y efecto agudo de la sesión después de un período de entrenamiento en individuos hipertensos, con edad 
a partir de 60 años, de ambos sexos. Los resultados apuntan que, a pesar de la heterogeneidad en los métodos de entrenamiento, todos los protocolos de intervención utilizados en estos estudios fueron eficaces en la promoción de la reducción de la PA postejercicio cuando comparados con el grupo control. Sin embargo, todavía existe un vacío en la literatura revisada con relación al tiempo de mantenimiento de la hipotensión postejercicio (HPE) en ancianos. Esta información podría sugerir por cuánto tiempo los practicantes estarían "protegidos" de los elevados valores presóricos y sus riesgos para la salud y auxiliar en la planificación de las sesiones de ejercicio físico, justamente cuando el efecto hipotensor estuviera dejando de manifestarse. Nivel de evidencia ll; Estudios terapéuticos-Investigación de los resultados del tratamiento.

Descriptores: Envejecimiento; Hipertensión arterial; Ejercicio físico; Hipotensión postejercicio.

\section{INTRODUCTION}

Aging is a universal phenomenon and longevity is currently identified as one of the most significant demographic transformations of the $21^{\text {st }}$ century. ${ }^{1}$ In developed and developing countries there has been a proportional reduction in the young population and an increase in the absolute number of older people. This process has multiple determinants, particularly the decline in birth rates, the increase in life expectancy and the reduction in mortality. ${ }^{2}$

Evidence of a progressively aging population has a direct impact on modern society, due to the significant demand for structural changes, especially those geared towards the public health area. As the number of older people grows, health problems also increase exponentially, with special emphasis on hypertension (HT) as one of the most prevalent diseases in the elderly population, ${ }^{3,4}$ while vascular aging is the main aspect related to blood pressure (BP) elevation in the elderly. ${ }^{5}$

According to the World Health Organization (WHO), HT causes widespread concern among health professionals, as it is associated with cardiovascular and cerebrovascular diseases, identified as the leading causes of death in the world. ${ }^{6} \mathrm{HT}$ affects approximately 1 billion people worldwide, contributing to 9.4 million deaths from cardiovascular diseases per year. In Brazil, HT affects about $25 \%$ of the population, of which over $50 \%$ is acquired at an advanced age, emphasizing aging as an alarming factor for its occurrence.?

The development of HT is not due to an isolated cause, but to a set of factors that may increase the likelihood of its onset. Its etiology is multifactorial and involves social, environmental, psychological and genetic variables. $^{8}$

To address this worrying public health problem, regular physical exercise is indicated as a non-pharmacological therapeutic tool for the treatment of HT. The VII Brazilian Guidelines on Hypertension pinpoint regular aerobic training as a preferential form of exercise, because it contributes both to the reduction of casual BP in pre-hypertensive and hypertensive individuals, and the reduction of awake BP in hypertensive individuals in situations of physical, mental and psychological stress. Due to its ability to produce an approximate systolic/diastolic blood pressure reduction of 2.1/1.7 in pre-hypertensive patients and 8.3/5.2 $\mathrm{mmHg}$ in hypertensive patients, respectively, physical exercise is of paramount importance for the prevention and treatment of HT. ${ }^{5}$ Lifestyle changes as well as regular and continuous aerobic exercise is, according to the European Society of Cardiology, a Class I recommendation and level of evidence B, with an estimated reduction of approximately $6.9 \mathrm{mmHg}$ in systolic blood pressure and $4.9 \mathrm{mmHg}$ in diastolic blood pressure. ${ }^{9}$ Reiterating this claim, the American College of Cardiology states that regular physical exercise is the best proven non-pharmacological intervention for the prevention and treatment of $\mathrm{HT}$, and can cause a reduction of 5 to $8 \mathrm{mmHg}$ in BP values. ${ }^{10}$

Although there is overwhelming evidence in the literature of the benefits of chronic adaptations resulting from regular physical exercise, the variety of factors involved in physical exercise is extensive (different exercise types, intensities, and durations), and it can thus elicit distinct acute responses, especially in elderly hypertensive individuals. Therefore, the purpose of this study was to conduct a systematic review of the last ten years on the acute effect of physical exercise on BP in hypertensive elderly individuals and its applicability to HT treatment.

\section{MATERIALS AND METHODS}

\section{Study search and selection strategy}

The search for articles on the effects of acute exercise on BP was performed from electronic databases available at Pubmed/Medline, Scopus and Bireme. The study was approved by the Institutional Review Board of the Universidade do Estado de São Paulo (IRB/FC-UNESP No. $2,422,919)$. The search was conducted using the terms "acute physical exercise and hypertension and elderly". This systematic review included only clinical trials published between January 2008 and December 2018, which investigated the acute effect of exercise on BP in elderly individuals (aged $\geq 60$ years), diagnosed with $\mathrm{HT}$. There were no restrictions imposed on the sex of the sample groups and the language of the studies. Reviews, meta-analyses, non-clinical trials, studies not involving physical exercise, animal studies, methodological or observational studies (descriptive only), and clinical trials that did not have the full text available were not included in the review. Due to the variability of the interventions, we only included articles with an analysis of the effect of an exercise session on BP. The literature search and evaluation of studies were carried out by two independent reviewers (TAR and AMGM). Articles were initially selected based on their title and abstract, and after both reviewers considered them eligible, studies were selected for full-text screening.

\section{Data extraction and analysis}

Data on study origin, sample size, participant characteristics (age, sex, baseline BP, physical activity level and comorbidities), method used to measure BP, intervention characteristics (type, frequency and duration of exercise), and results and limitations were extracted from studies included independently by two authors (TAR and AMGM). In the event of discordance between the reviewers, a third author (RFDS) was consulted. The methodological quality of the studies included was assessed using the PEDro scale (www.pedro.org.au). The results of the systematic review are presented descriptively (mean, standard deviations and minimum and maximum values).

\section{RESULTS}

The database search resulted in the selection of 592 articles, of which 449 were removed as they were not clinical trials. Of the 143 clinical trials, 84 were published before January 2008 and one was not available in the full text version. Of the 58 remaining clinical trials, 49 were removed because the population age was $<60$ years, the subjects 
were normotensive, or the trials did not involve exercise. Finally, after applying the eligibility criteria, we included nine articles in this review that evaluated only the acute effect of the exercise session (six studies) and acute effect of the session after a training period (three studies) on $\mathrm{BP}$ in hypertensive older people (Figure 1).

\section{Study and characteristics of the subjects}

The general description of each study is presented in Table 1. Nine articles were selected for the final analysis, six of which are considered crossover ${ }^{11-16}$ and three parallel design. ${ }^{17-19}$ As regards the trials, three are randomized and non-controlled. $12,15,16$ Only one study presented samples of normotensive and hypertensive patients, ${ }^{17}$ while the other articles only presented hypertensive patients. Seven articles were conducted with hypertensive women, one article considering both sexes ${ }^{11}$ and another including only men, ${ }^{13}$ while all the studies included participants aged between 60 and 80 years. Six studies assessed the acute effect of a single exercise session on BP with a sample size of 15-20 participants (totaling 106 participants), including only women, or only men or both sexes. Three studies assessed the acute effect of a single exercise session after a training period with a sample size of 20 to 64 participants (totaling 148 participants), including women only. In most studies, BP was measured by a digital or oscillometric device; only one study used the auscultatory method ${ }^{11}$ and two studies used 24-hour ambulatory blood pressure monitoring (ABPM). ${ }^{11,13}$ The methodological quality of the studies was assessed using the PEDro scale (Figure 2), with a mean PEDro score of 6.6 ranging from five to ten.

\section{Effect of interventions on BP}

The main results and conclusions of the different interventions are described in Table 2. It can be observed that there was a reduction in $\mathrm{BP}$ in all protocols when compared to the control intervention, but the results of this review showed some dissimilar effects on the different types of physical exercise, intensity and duration.

\section{DISCUSSION}

This systematic review evaluated the acute effect of physical exercise on BP in hypertensive elderly patients and its applicability to the treatment of HT. We found nine articles published in the last ten years.
The studies included in this article were found to contain a significant variety of training protocols, of which four used only muscle resistance exercises, ${ }^{11,15,17,18}$ one used resistance exercises in combination with vascular occlusion, ${ }^{14}$ another three combined resistance and aerobic exercises ${ }^{12,13,19}$ and only one study used aerobic exercise alone, which was also associated with vascular occlusion. ${ }^{16}$ Associated with the different types of exercises used, we also observed different intensities and durations of exercise sessions. Accordingly, it is important to emphasize that the physiological mechanisms involved in BP control and its relationship with the different ways in which physical exercise can be performed are not yet fully established, and may make a greater or lesser contribution to the reduction of BP values according to the training protocol used.

Among the studies included in this review, six analyzed only post-exercise BP reduction following an acute physical exercise session 11,13-17 while the other three repeated the analysis after a training period, assessing not only the acute effect alone, but also chronic adaptation and its effect on the magnitude of PEH. ${ }^{12,18,19}$ The above observation shows that physiological and structural adaptations arising in the respective training periods of the studies, despite the use of different training protocols, may contribute to a better hypotensive effect both in chronic terms and in acute responses. A possible hypothesis is that under both conditions the shear stress stimulated by physical exercise (acute or chronic) acts on the endothelial cells which, through a cascade of events, lead to the production of the enzyme endothelial nitric oxide synthase, generating vasodilation and as a consequence the reduction of BP values. ${ }^{20}$

As indicated by the VII Brazilian Guidelines on Hypertension, ${ }^{5}$ among other guidelines, aerobic treatment is recommended as a preferential option for the prevention and treatment of HT, a fact that draws attention when we observe that only one of the nine studies used aerobic exercise in its experimental protocol, in combination with vascular occlusion. Associated with this fact, there is a predominance of protocols using resistance and combined exercise, with only one investigation that combined resistance exercise with vascular occlusion. All protocols presented satisfactory post-exercise BP reduction results, demonstrating the search for innovative proposals in exercise planning for hypertensive patients, especially those with some limitation regarding overload, since the protocols that used vascular occlusion and lighter loads also had beneficial results in BP values.

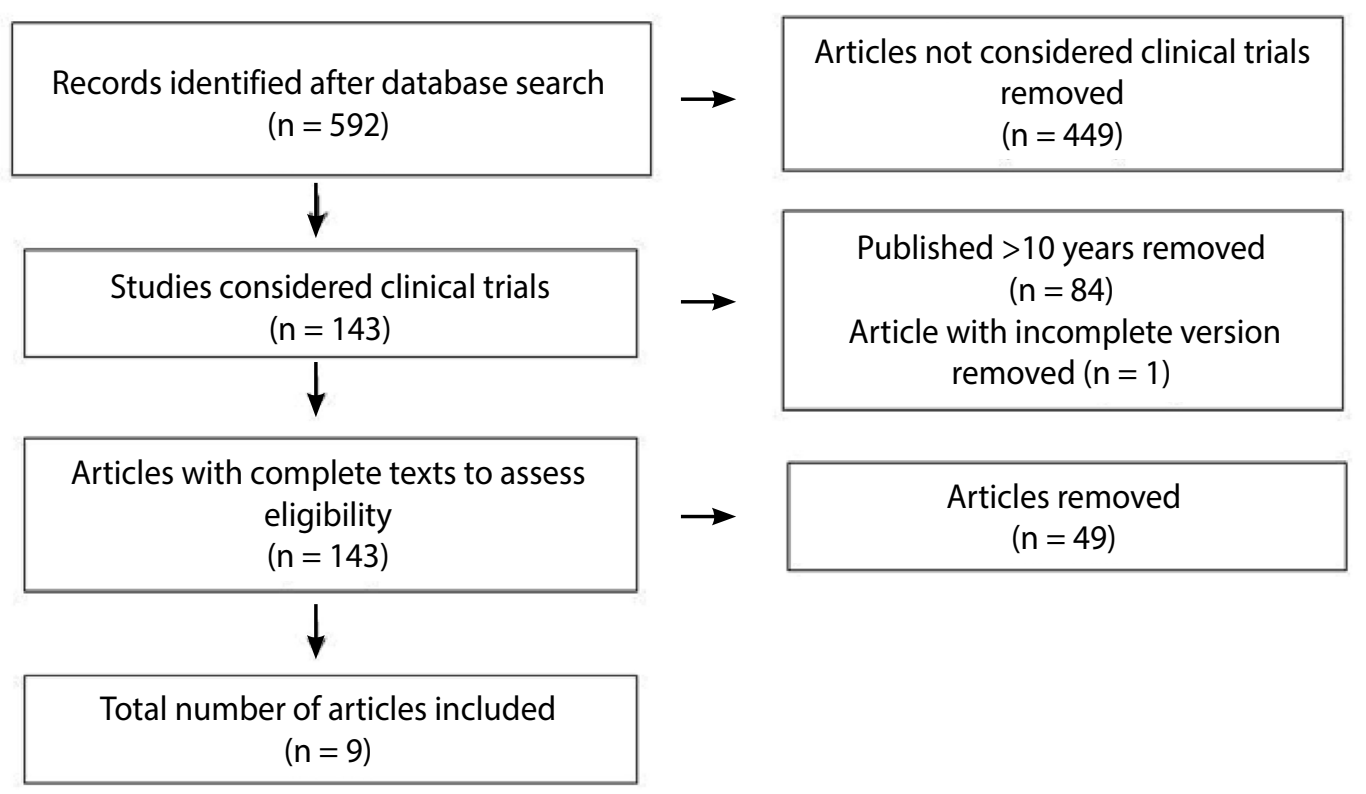

Figure 1. Study selection process. 
Table 1. General characteristics of the studies.

\begin{tabular}{c|c}
\hline $\begin{array}{c}\text { Author(s) / Year/ } \\
\text { Type of study }\end{array}$ & Sampling \\
\hline
\end{tabular}

articipants ( 7

16 hypertensive participants (7

Scher et al., 201111/ men/9 women, average age $67.6 \pm$ crossover 65.1) were randomized to exercise sessions 1 (E1), 2 (E2), and control.

Mota et al.,
$2013^{18} /$ paralle

$2013^{18}$ / parallel

( $n=32$, average age 66.8 \pm 5.4).

Dos Santos et al.,

60 hypertensive women randomized 2014 19 parallel in TRT ( $n=20$, age 62.6 \pm 2.5$)$, ERT $(n=20$, age 64.2 \pm 3.1$)$ and CG ( $n=20$, age 63.1 \pm 2.3$)$.

64 hypertensive women were randomized in the $E G(n=32$, average age $67.5 \pm 7$ ) and CG $(n=32$, average age $66.8 \pm 5.4)$.

CG $(n=20$, age 63.1 $1 \pm 2.3)$.
$2016^{12} /$ crossover

20 hypertensive women (age 66.8 \pm 5.6 undergoing the acute physical exercise session and the chronic training.

\begin{tabular}{l|l|} 
& session and the chronic training. \\
\hline &
\end{tabular}

Pinto et al., 2018 14 / 18 hypertensive women (age 67 \pm 1.7 ) crossover randomized in TVO, TWVO and CG.

\begin{tabular}{|c|c|}
\hline $\begin{array}{l}\text { Coelho-Júnior et } \\
\text { al., } 20177^{17} / \text { parallel }\end{array}$ & $\begin{array}{l}21 \text { normotensive }(n=11) \text { and } \\
\text { hypertensive }(n=10) \text { women } \\
\text { randomized in } S T(n=11 \text {, age } \\
66.7 \pm 4.7), R T(n=10 \text {, age } 67.5 \pm 4.4) \\
\text { and } C G(n=10 \text {, age } 66.8 \pm 5.4) \text {. }\end{array}$ \\
\hline
\end{tabular}

Ferrari et al., $2017^{13} /$ crossover

20 hypertensive men (age $65.3 \pm 3.3$ ) randomized in $A E$, ARE and $C G$.

\begin{tabular}{c|c} 
& \\
\hline Orsano et al., & 15 hypertensive women (age 67.1 \\
$2018^{15} /$ crossover & randomized in RT and HSRT.
\end{tabular}

\begin{tabular}{|c|c|}
\hline $2018^{15} /$ crossover & randomized in RT and HSRT. \\
\hline $\begin{array}{l}\text { Barili et al., } 2018^{16} \\
\text { cross over }\end{array}$ & $\begin{array}{c}16 \text { hypertensive women (age } \\
67 \pm 3.7) \text { randomized in HIAE, } \\
\text { LIAE and LIAE + VO. }\end{array}$ \\
\hline
\end{tabular}

Moreira et al.,

\section{Experimental intervention}

E1: 20min of resistance exercises (1 lap around the circuit).

E2: $40 \mathrm{~min}$ of resistance exercises

(2 laps around the circuit).

Both sessions adopted intensity of $40 \%$ of 1 RM.
Control intervention

BP was measured every 5 min using the auscultatory and oscillometric methods

for $20 \mathrm{~min}$ before the sessions.

After each session, BP was measured every $5 \mathrm{~min}$ for $60 \mathrm{~min}$. ABPM was installed and $\mathrm{BP}$ was automatically measured every $15 \mathrm{~min}$ or $20 \mathrm{~min}$ for $2 \mathrm{~h}$.

EG: Month 1: 3 weeks of adaptation; Month 2: 16 resistance exercise sessions at $60 \%$ of 1RM; Month 3: 16 resistance exercise sessions at 70\%; Month 4: 16 resistance exercise sessions at $80 \%$.

$40 \mathrm{~min}$ of rest in the

sitting position.

every 15 min or $20 \mathrm{~min}$ for $2 \mathrm{~h}$.

BP was assessed with an automatic device and HR with a specific monitor. Variables were measured with participants sitting
in all exercise and control sessions, every

Did not perform any exercise. resistance exercise, and also every $15 \mathrm{~min}$
Parameters measured
$5 \mathrm{~min}$ for $20 \mathrm{~min}$ at pre-exercise rest and after during a $1 \mathrm{~h}$ post-exercise recovery period.

The protocols were combined with 20min of aerobic exercise, 3 times a week for 16 weeks. TRT Group: between 1 and 5 weeks at $70 \%$ of $10 \mathrm{RMs}, 6-11$ at $80 \%$ and $12-16$ at $90 \%$ of $10 \mathrm{RMs}$, with an average duration to complete 1 repetition of 3-4 sec in both phases. ERT: between 1-5 weeks at 100\% of 10RMs, 6-11 at $110 \%$ and $12-16$ at $120 \%$ with an average duration of 1 repetition of 2-3s (eccentric phase and aid in the concentric phase).

The acute exercise session consisted of 10 resisted exercises on machines at $60 \%$ of 1 RM. Participants then underwent progressive RE training for 12 weeks at $60-80 \%$ of $1 \mathrm{RM}$.

TVO group performed 3 sets of 10 repetitions at $20 \%$ of $1 \mathrm{RM}$ with VO. The TWVO group performed 3 sets of 10 repetitions at $65 \%$ of $1 \mathrm{RM}$ without $\mathrm{VO}$. Both exercise sessions were performed on the knee extension equipment with a 1 min interval between sets.

RT: 3 sets of 8 to 10 repetitions of each exercise at $70 \%$ of $1 \mathrm{RM} ;$ ST: 3 sets of 8 to 10 repetitions of each exercise at $50 \%$ of 1 RM. In the ST each repetition should be performed at the highest possible speed.

\section{AE: 45 min of walking on the} treadmill at $65-70 \%$ of $\mathrm{VO}_{2 \max }$. ARE: 20 min of resistance exercises at $70 \%$ of $1 \mathrm{RM}$, followed by $25 \mathrm{~min}$ of aerobic exercise at $65-70 \%$ of $\mathrm{VO}_{2 \max }$.

Both sessions consisted of 10 exercises at $70 \%$ of 10 RM with $1 \mathrm{~min}$ interval between sets. The RT group completed the concentric and eccentric phases of movement at a moderate pace (2-3s each), and the HSRT group completed the concentric phase as quickly as possible.

Each subject performed 3 experimental protocols on the treadmill: HIAE (aerobic exercise at $50 \%$ of $\mathrm{VO}_{2 \max }$ ); LIAE (aerobic exercise at $30 \%$ of $\mathrm{VO}_{2 \max }$ and LIAE + VO (aerobic exercise at $30 \%$ of $\mathrm{VO}_{2 \max }$ with blood flow restriction at a pressure equivalent to $130 \%$ of SBP measured at rest).

BP was measured by an oscillometric device and $\mathrm{HR}$ by a monitor after 10, 15, 30, 45 and $60 \mathrm{~min}$ (time 1,2, 3 and 4) of rest after Did not perform control or exercise sessions. Post-exercise BP any exercise. $\quad$ reduction was analyzed in the first training session after RT familiarization and strength testing, and chronic hypotension was measured after the last training session.

$\mathrm{BP}$ and $\mathrm{HR}$ were measured using a digital automatic device after $20 \mathrm{~min}$ of rest in the pre-intervention period and for 60 min after the RE session. These pre-

exercise data from the acute session were also used to analyze chronic effects.

BP was measured by a digital device after $10 \mathrm{~min}$ of rest and was also obtained

Absence of using continuous noninvasive digital exertion with VO. photoplethysmography during the experimental and control sessions.

BP was measured 20 min before the Did not perform $\quad \begin{gathered}\text { experimental sessions and for } 1 \mathrm{~h} \text { after } \\ \text { the exercises }(5,10,15,30,45 \text { and } 60 \mathrm{~min})\end{gathered}$ any exercise. using an automated oscillometric device.

BP was measured by an oscillometric device after $20 \mathrm{~min}$ of rest before the sessions. After $45 \mathrm{~min}$ of rest in the the sessions, BP was measured every $5 \mathrm{~min}$ for \begin{tabular}{l|l} 
sitting position. & $1 \mathrm{~h}$. ABPM was installed and BP was measured
\end{tabular} automatically every $15 \mathrm{~min}$ during the day $(11 \mathrm{~h}$ to $22 \mathrm{~h}$ ) and every $20 \mathrm{~min}$ at night (22h to $6 \mathrm{~h}$ ).

BP was measured after 15 min of rest (time point 0 ) before the sessions and at 5 , 15,30 and $45 \mathrm{~min}$ after the experimental sessions using an oscillometric device.

Absent.

$\mathrm{BP}$ was measured after $15 \mathrm{~min}$ of rest before the experimental protocols, after the exercise session, and 30min after recovery.

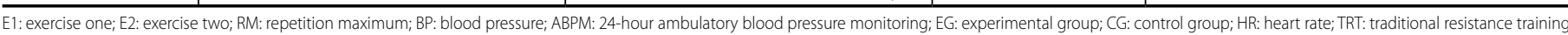

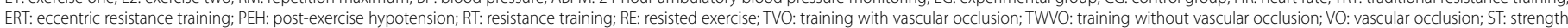

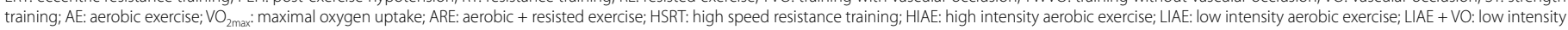

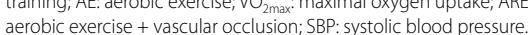




\begin{tabular}{|c|c|c|c|c|c|c|c|c|c|c|c|c|}
\hline & \multicolumn{12}{|c|}{ PEDro criteria } \\
\hline $\begin{array}{c}\text { Author } \\
\text { and year }\end{array}$ & Eligibility & $\begin{array}{l}\text { Subjects } \\
\text { were } \\
\text { randomly } \\
\text { assigned }\end{array}$ & \begin{tabular}{c|} 
Blind \\
Distribution
\end{tabular} & $\begin{array}{l}\text { Similar } \\
\text { Groups }\end{array}$ & $\begin{array}{l}\text { Subjects } \\
\text { were } \\
\text { blinded }\end{array}$ & $\begin{array}{c}\text { Therapists } \\
\text { were } \\
\text { blinded }\end{array}$ & $\begin{array}{c}\text { Assessors } \\
\text { were } \\
\text { blinded }\end{array}$ & $\begin{array}{c}\text { Results } \\
\text { measured } \\
\text { in }>85 \% \text { of } \\
\text { participants }\end{array}$ & $\begin{array}{l}\text { Intent- } \\
\text { to-Treat } \\
\text { analysis }\end{array}$ & $\begin{array}{l}\text { Intergroup } \\
\text { comparison }\end{array}$ & $\begin{array}{c}\text { Measures of } \\
\text { variability }\end{array}$ & Total \\
\hline $\begin{array}{c}\text { Scher et } \\
\text { al., } 2011^{11}\end{array}$ & S & $S$ & N & S & N & N & N & $S$ & S & $S$ & S & $6 / 10$ \\
\hline \begin{tabular}{|} 
Mota et \\
al., $2013^{18}$
\end{tabular} & $S$ & S & N & S & N & $\mathrm{N}$ & N & S & S & S & S & $6 / 10$ \\
\hline $\begin{array}{l}\text { Dos Santos } \\
\text { et al., 2014 }\end{array}$ & S & S & N & S & N & N & N & S & S & S & S & $6 / 10$ \\
\hline $\begin{array}{l}\text { Moreira et } \\
\text { al., 2016 }\end{array}$ & $S$ & N & N & S & N & N & N & S & S & $S$ & S & $5 / 10$ \\
\hline $\begin{array}{l}\text { Coelho- } \\
\text { Júnior et } \\
\text { al., } 2017^{17}\end{array}$ & $S$ & $S$ & S & $S$ & S & $\mathrm{N}$ & $\mathrm{N}$ & $S$ & S & S & S & $8 / 10$ \\
\hline $\begin{array}{l}\text { Ferrari et } \\
\text { al., } 2017^{13}\end{array}$ & $S$ & $S$ & S & S & $S$ & $S$ & $S$ & $S$ & $S$ & $S$ & $S$ & $10 / 10$ \\
\hline $\begin{array}{c}\text { Pinto et } \\
\text { al., } 2018^{14}\end{array}$ & S & $S$ & N & S & N & $\mathrm{N}$ & N & S & S & S & S & $6 / 10$ \\
\hline $\begin{array}{l}\text { Orsano et } \\
\text { al., } 2018^{15}\end{array}$ & $S$ & $S$ & $\mathrm{~N}$ & $S$ & $\mathrm{~N}$ & $\mathrm{~N}$ & $\mathrm{~N}$ & $S$ & S & S & S & $6 / 10$ \\
\hline $\begin{array}{c}\text { Barili et al., } \\
2018^{16}\end{array}$ & S & $S$ & S & S & N & N & N & S & S & S & S & $7 / 10$ \\
\hline
\end{tabular}

Figure 2. PEDro classification for the studies included.

The considerable heterogeneity in training methods may have resulted in different responses in BP behavior. However, it is important to note that all intervention protocols carried out in the studies selected in this systematic review were effective in promoting post-exercise BP reduction when compared to the control group, but the absence of post-exercise BP monitoring in most studies ruled out the possibility of evaluating the duration of post-exercise hypotension (PEH). Only two articles $^{11,21}$ used ABPM in their experimental protocols to effectively evaluate the hypotensive effect for up to $24 \mathrm{~h}$ after an acute exercise session, which makes it possible to measure how long PEH lasted, thus demonstrating a period of time in which exercisers can be "protected" from elevated blood pressure values and their associated health risks.

This observation is relevant to future studies since it would enable us to measure which of the interventions results in desirable pressure responses, and for how long the PEH status lasts. This would allow us to verify, for example, the optimal time for application of a new exercise overload, precisely when the hypotensive effect has ceased. Thus, following the basic principles of physical training, it would be possible to construct an overcompensation curve of the hypotensive effect for each type of exercise performed, such that, knowing the dose-response effect of the physical exercise undertaken, its application would be similar to the administration of a drug or combination of drugs with expected pharmacological effect.

Regarding the methodological quality of the studies included, assessed by the PEDro Scale, all were methodologically deficient, and only one study met all the criteria, which reinforces the risk of bias for interpretation and comparison of data, since most of the studies are subject to limitations such as the blinding of patients, therapists and assessors in treatment conditions, besides the lack of randomization and control.

\section{Implications for clinical practice}

Despite the distinction between exercise and/or training protocols used in the studies analyzed, the effect of PEH can be observed in all studies, a fact that may provide more support when planning physical training for both prevention and treatment of HT.

\section{Limitations}

This review was limited by the heterogeneity of intervention programs and variety in BP measurement protocols. In addition, the different equipment used, as well as the time points at which BP was measured, may influence the interpretation of PEH to compare the effect of the protocols of this particular study.

\section{CONCLUSIONS}

All the reviewed articles, regardless of the methods used, were effective in promoting post-exercise BP reduction. However, there is still a gap in the reviewed literature regarding the maintenance time of PEH in the elderly. This information could suggest how long individuals undergoing physical exercise would be "protected" from high blood pressure values and their health risks, and help plan exercise sessions at the precise time the hypotensive effect ceases to exist.

\section{ACKNOWLEDGMENTS}

This study was supported by the CAPES (Higher Education Personnel Upskilling Coordination Office).

All authors declare no potential conflict of interest related to this article 
Table 2. Main results and conclusions of the studies.

\begin{tabular}{|c|c|c|}
\hline Author/Year & Results & Conclusion \\
\hline Scher et al., $2011^{11}$ & 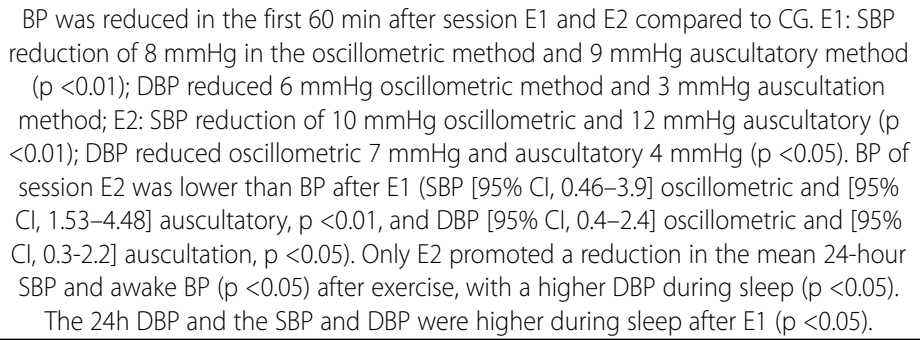 & $\begin{array}{l}\text { Acute sessions of resisted exercise at } 40 \% \text { intensity with } \\
\text { different volumes reduced BP during the first } 60 \mathrm{~min} \text { in } \\
\text { hypertensive elderly subjects. However, only the highest } \\
\text { volume promoted a reduction in mean } 24 \mathrm{~h} \text { and awake SBP. }\end{array}$ \\
\hline
\end{tabular}

SBP: at month 3 there was a significant difference in $30 \mathrm{~min}(p=0.009)$ and

45 min $(p=0.05)$ recovery period between EG and CG. At month 4 there was

Dos Santos et al., $2014^{19}$ TRT; in DBP there was a reduction of $12.03 \pm 1.23$ in ERT and $8.12 \pm 1.10$ in TRT. $\mathrm{PEH}$ in the ERT group underwent a reduction of $4.01 \pm 0.37$ in SBP in a greater magnitude than TRT, which had a reduction of $2.52 \pm 0.388 \mathrm{mmHg}$. In DBP there was a reduction of $4.93 \pm 0.95$ in the ERT and $4.17 \pm 0.57$ in the TRT.

There were no acute reductions in $\mathrm{BP}$, but chronic reduction was observed. There were significant chronic decreases in SBP and DBP in participants with acute SBP and DBP reduction $(p<0.05)$. SBP changes after acute RE session were correlated with chronic changes in resting SBP after training ( $r=0.47 ; p=0.03)$. Similar correlations between acute and chronic responses were also observed for DBP $(r=0.70 ; p=0.01)$, mean $B P(r=0.58 ; p=0.01)$, and HR $(r=0.73 ; p<0.01)$.

Moreira et al., $2016^{12}$

Significant elevation in SBP and DBP $(p<0.05)$ at all time points of the experimental sessions compared to the control session. SBP and DBP were lower during rest intervals in the session with VO $(p<0.05)$. A significant difference was observed in SBP and DBP at the pre and post-session time points, but the TVO tended to reduce SBP (from $132.7 \pm 3.1$ to $129.8 \pm 2.9 \mathrm{mmHg}$ ) and DBP (from $76.0 \pm$ 2.3 to $74.2 \pm 2.5 \mathrm{mmHg}$ ), while the TWVO increased SBP (from $130.3 \pm 4.2$ to $138.5 \pm 5.9 \mathrm{mmHg}$ ) and reduced DBP (from $73.2 \pm 1,8$ to $71.1 \pm 2.4 \mathrm{mmHg}$ ).

Pinto et al., $2018^{14}$

\begin{tabular}{l|l}
$138.5 \pm 5.9 \mathrm{mmHg})$ and reduced \\
\hline SBP in the ST group decreased by $10(-7.8 \pm 8.0), 15(7.3 \pm 7.4), 30 \mathrm{~min}(-9.1$
\end{tabular}

Coelho-Júnior et al., $2017^{17}$ $\pm 10.0)$ and $45 \mathrm{~min}(-7.5 \pm 10.2)$ after the exercise session compared with rest ( $p=0.001$ ), while RT showed no significant difference despite a downtrend.

DBP showed no significant difference in the CG, RT and ST groups. a significant difference at all recovery times $(p \leq 0.05)$. Acute PEH at months 2 (from $134.5 \pm 14.6$ to $126.4 \pm 16.5$ ) and 3 (from $124.9 \pm 11.8$ to $121.6 \pm$

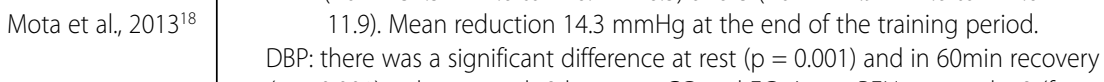
$(p=0.001$ ) only at month 2 between CG and EG. Acute PEH at months 2 (from $80.9 \pm 11.1$ to $73.0 \pm 10.0$ ) and 4 (from $72.4 \pm 9.3$ to $69.7 \pm 9.2$ ). Mean reduction of $3.6 \mathrm{mmHg}$ at the end of the training period. The CG had no variation.

There were significant interactions in the groups for lower SBP and DBP than in the CG. When the pre and post intervention periods were compared, there was a reduction in SBP of $6.94 \pm 0.2$ in the ERT group and $4.17 \pm 0.57 \mathrm{mmHg}$ in the

Resistance training at $60 \%$ and $70 \%$ of 1RM was able to generate a reduction in post-exercise SBP in hypertensive women, while DBP underwent a $60 \%$ and $80 \%$ of 1 RM post-exercise reduction. The 4 -month period contributes to a chronic reduction in the EG BP.

Both protocols of RT combined with aerobic exercise were effective in reducing BP after 16 weeks. Postexercise SBP reduction was correlated with the magnitude of change in BP after chronic RT only in the ERT. ERT in combination with aerobic exercise is safe and effective for elderly hypertensive women.

Acute $B P$ responses after a single RE session were associated with chronic changes in BP after the training program. This finding makes the magnitude of changes in BP a promising candidate for predicting BP-related individuals, which may contribute to the prescription of resistance training in hypertensive patients.

Although there was no significant difference between pre and post BP values in the experimental sessions, TVO presented lower BP values during the intervals at all time points and a tendency to decrease at the post-session time point, besides being easier to perform as the participants were expected to lift lighter loads until failure, proving to be a safer method for hypertensive women as compared to TWVO.

An acute session of ST and RT may be effective in causing benefits for BP, but ST has been shown to be superior in inducing a reduction in SBP, indicating the potential of this type of physical training to be used as a non-pharmacological tool in the treatment of hypertensive elderly women.

DBP was lower after AE and ARE compared to the CG at 20min of recovery $(p<0.05)$; mean BP was lower after AE and ARE compared to the CG from 10 to $50 \mathrm{~min}$ of recovery $(p<0.05)$. SBP decreased after $A E$ from 10 to 50 min of recovery and after the ARE session from 10 to $40 \mathrm{~min}(p<0.05)$. In the CG no immediate effect was observed. DBP decreased after ARE from 10 to $40 \mathrm{~min}$ of recovery and at $10 \mathrm{~min}$ after the AE session, while it increased 10, 40,50 and 60min after control session $(p<0.05)$. Mean BP decreased after ARE from 10 to $30 \mathrm{~min}$ of recovery and after the AE session at $10 \mathrm{~min}$ of recovery, while it increased from 40 to $60 \mathrm{~min}$ after control session $(p<0.05)$. During the first hour after the sessions, DBP was lower after AE $(-5 \mathrm{mmHg})$ and ARE $(-6 \mathrm{mmHg})$ compared to the CG. Daytime DBP was significantly lower after AE $(-7 \mathrm{mmHg})$ when compared to the CG. No significant differences were found between the three experimental sessions for DBP.

There was no significant difference in SBP between the experimental sessions at baseline and for $30 \mathrm{~min}$ after the sessions. DBP did not change significantly ( $p>0.05$ ) between conditions at baseline and for $45 \mathrm{~min}$ after the sessions. SBP was significantly higher $(p=0.049)$ for the HSRT session compared with RT only after $45 \mathrm{~min}$ of exercise. SBP was also significantly higher $(p<0.05)$ at 30 and 45 min after the HSRT session compared with resting values, while it was significantly higher $(p<0.05)$ at time point 0 only after the RT session in comparison with rest values. DBP was significantly higher $(p<0.05)$ after time point 0 and after $5 \mathrm{~min}$ only after the RT session in comparison with rest values.

BP increased from rest to post-exertion $(p<0.05)$ and decreased from postexertion to recovery $(p<0.05)$ in all protocols. SBP and DBP returned to resting levels after the recovery period in LIAE and LIAE + VO. However, in the LIAE protocol, BP was lower after recovery compared to the rest period $(p<0.05)$.
Combined exercise produced acute PEH similar to aerobic exercise, but this effect did not last as long as aerobic exercise in hypertensive elderly subjects.

During the first hour after the sessions, DBP was lower after AE $(-5 \mathrm{mmHg})$ and ARE $(-6 \mathrm{mmHg})$ compared to the CG. Daytime DBP was significantly lower after $\mathrm{AE}(-7 \mathrm{mmHg})$ when compared to the CG. No significant differences were found between the three experimental sessions for nighttime and 24h DBP, or for daytime, nighttime and 24h BP.

Both HSRT and RT performed at the study intensity and volume present benefits in acute BP responses, suggesting they are safe for elderly hypertensive women receiving medication.

The results support the indication of LIAE and LIAE + VO in chronic intervention protocols with potential benefits for hypertensive elderly patients. 
AUTHORS' CONTRIBUTIONS: Each author made significant individual contributions to this manuscript. TAR: writing, revision, preparation of the entire research project and data analysis; RFS: writing, revision and intellectual concept; AMJ: writing, revision and data analysis; AMGM: writing, revision and data analysis; ABS: writing, revision and intellectual concept; HLM: writing, revision and intellectual concept; ASZ: revision, intellectual concept. All authors reviewed and approved the final version of the manuscript

\section{REFERENCES}

1. ONU. Envelhecimento no Século XXI: celebração e desafio. Nova York: UNFPA, 2012.

2. Lin RT, Chen YM, Chien LC, Chan CC. Political and social determinants of life expectancy in less developed countries: a longitudinal study. BMC Public Health. 2012;12:85.

3. Cipullo JP, Martin JF, Ciorlia LA, Godoy MR, Cação JC, Loureiro AA, et al. Prevalência e fatores de risco para hipertensão em uma população urbana brasileira. Arq Bras Cardiol. 2010;94(4):519-26.

4. Pereira JC, Barreto SM, Passos VM. O perfil de saúde cardiovascular dos idosos brasileiros precisa melhorar: estudo de base populacional. Arq Bras Cardiol. 2008;91(1):1-10.

5. Cardiologia SBD. VII Diretrizes de Hipertensão Brasileira. Arq Bras Cardiol. 2016.

6. WHO. Cardiovascular diseases (CVDs): fact sheet. 2017[access on 201806 12]. Available at: https://www. who.int/news-room/fact-sheets/detail/cardiovascular-diseases-(cvds).

7. Malachias MV, de Souza WK, Lotemberg AM, Guimarães AC, Negrão CE, Forjaz CL. Diretrizes Brasileiras de Hipertensão VI. Rev Hipertensão. 2010;13(1):1-66.

8. Parati G, Ochoa JE, Lombardi C, Bilo G. Assessment and management of blood-pressure variability. Nat Rev Cardiol. 2013;10(3):143-55.

9. Perk J, De Backer G, Gohlke H, Graham I, Reiner Z, Verschuren M, et al. European Guidelines on cardiovascular disease prevention in clinical practice (version 2012). The Fifth Joint Task Force of the European Society of Cardiology and Other Societies on Cardiovlascular Disease Prevention in Clinical Practice (construted by representatives of nine societies and by invited experts). Eur Heart J. 2012;33(13):1635-701.

10. Whelton PK, Carey RM, Aronow WS, Casey DE jr, Collins KJ, Dennison Himmelfarb C, et al. 2017 ACC/AHA/AAPA/ABC/ACPM/AGS/APhA/ ASH/ASPC/NMA/PCNA Guideline for the prevention, detection, evaluation and management of high blood pressure in adults: a report of the American College of Cardiology/American Heart Association Task Force on Clinical Practice Guidelines.J Am Coll Cardiol. 2018;71(19):e127-248.

11. Scher LM, Ferriolli E, Moriguti JC, Scher R, Lima NK. The effect of different volumes of acute resistance exercise on elderly individuals with treated hypertension. J Strength Cond Res. 2011;25(4):1016-23.

12. Moreira SR, Cucato GG, Terra DF, Ritti-Dias RM. Acute blood pressure changes are related to chronic effects of resistance exercise in medicated hypertensive elderly women. Clin Physiol Funct Imaging. 2016;36(3):242-8.

13. Ferrari R, Umpierre D, Vogel G, Vieira PJ, Santos LP, de Mello RB, et al. Effects of concurrent and aerobic exercises on postexercise hypotension in elderly hypertensive men. Exp Gerontol. 2017;98:1-7.

14. Pinto RR, Karabulut M, Poton R, Polito MD. Acute resistance exercise with blood flow restriction in elderly hypertensive women: haemodynamic, rating of perceived exertion and blood lactate. Clin Physiol Funct Imaging. 2018;38(1):17-24.

15. Orsano VS, de Moraes WM, de Sousa NM, de Moura FC, Tibana RA, Silva AO, et al. Comparison of the acute effects of traditional versus high velocity resistance training on metabolic, cardiovascular, and psychophysiological responses in elderly hypertensive women. Clin Interv Aging. 2018;13:1331-40.

16. Barilli A, Corralo VD, Cardoso AM, Mânica A, Bonadiman BD, Bagatini MD, et al. Acute responses of hemodynamic and oxidative stress parameters to aerobic exercise with blood flow restriction in hypertensive elderly women. Mol Biol Rep. 2018;45(5):1099-1109.

17. Coelho-Júnior HJ, Irigoyen MC, Aguiar SS, Gonçalves IO, Câmara NO, Cenedeze MA, et al. Acute effects of power and resistance exercises on hemodynamic measurements of older women. Clin Interv Aging. 2017;12:1103-14.

18. Mota MR, Oliveira RJ, Terra DF, Pardono E, Dutra MT, de Almeida JA, et al. Acute and chronic effects of resistive exercise on blood pressure in hypertensive elderly women. Int J Gen Med. 2013;6:581-7.

19. Dos Santos ES, Asano RY, Filho IG, Lopes NL, Panelli P, Nascimento DC, et al. Acute and chronic cardiovascular response to 16 weeks of combined eccentric or traditional resistance and aerobic training in elderly hypertensive women: a randomized controlled trial. J Strength Cond Res. 2014;28(11):3073-84.

20. Ferrari AU, Radaelli A, Mori I, Mircoli L, Perlini S, Meregalli P, et al. Nitric oxide-dependent vasodilation and the regulation of arterial blood pressure. J Cardiovasc Pharmacol. 2001;38(Suppl 2):S19-22. 